identified several Cameroons figure-sculptures as 'royal portraits' on the basis of their imagery. Douglas Fraser of Columbia called attention to iconographic features of fishlegged figures from Benin that suggest a Late Antique-Eastern Empire ancestry for this form. An expanded version of the proceedings including additional essays on Kuba, Baoule, and Chokwe art is now being prepared for publication. The Department of Art History, Columbia University, plans to sponsor future symposia on other aspects of nonWestern art.

\title{
Michigan State University: African Dance Course
}

'AfRICAN DANCE', the first American University course devoted to the indigenous dances of tropical Africa, was offered during the Spring 1965 Term at Michigan State University by Judith Lynne Hanna and jointly sponsored by the African Studies Center and the Department of Health, Physical Education, and Recreation.

The course had a twofold approach: (I) the functions and (2) the structures and styles of African dance. The former included such issues as the relationship of dance to the society of which it is a part, and its impact on the performers and spectators. The structural and stylistic approach considered how the elements of dance (space, dynamics, and rhythm) are used. A bibliography of ninety-three items, which is available on request, was specially prepared for the course. Students had an opportunity to see demonstrated and to participate in dances from the following ethnic groups: Acholi, Danakil, Ganda, Giriama, Gurage, Ibo, Iteso, Kamba, Luo Menjar, Nandi, Nyoro, Samburu, Somali, Tusi, Wolamo, and Yoruba.

\section{Research Fellowships for African Studies}

The American Social Science Research Council has awarded the following Research Training Fellowships for African Studies:

Enid Schildkrout (Cambridge, England): immigrant communities in Ghana.

Philip Silverman (Cornell): political change in Barotseland.

\section{Research Grants from the Scandinavian Institute of African Studies}

THE Board of the Institute of African Studies at the University of Uppsala has awarded grants for African Studies in 1965 for the following piojects :

Gunilla Beckman (Stockholm): significance of industrialization for the distribution of population, especially urbanization in Ghana.

Gunnar Carlsson (Lund): problems concerning simulium damnosum as the carrier of onchocerciasis in Upper Volta.

Lars Rudebeck (Uppsala): The one party system in Tunisia.

Professor Bengt Sundkler (Uppsala): Separatist African religious groups in Swaziland, Zululand, and Johannesburg.

\section{Activités récentes de l'Institut National Tchadien pour les Sciences Humaines}

Fondé en 196r, l'Institut National Tchadien pour les Sciences Humaines (I, Place de l'Indépendance, B.P. 503, Fort-Lamy, République du Tchad) poursuit, en liaison avec le C. N. R. S., principalement, son programme de recherche sous la direction du Professeur J.-P. Lebeuf, Directeur de Recherche au C. N. R. S. A l'Institut ont été rattachés le Musée 